\title{
Sexual Orientation and the Paradox of Heightened Scrutiny
}

Nan D. Hunter

Georgetown University Law Center, ndh5@law.georgetown.edu

Reprinted from Michigan Law Review, June 2004, Vol. 102, No. 7. Copyright 2004 by Nan D. Hunter.

This paper can be downloaded free of charge from:

https://scholarship.law.georgetown.edu/facpub/114

102 Mich. L. Rev. 1528-1554 (2004)

This open-access article is brought to you by the Georgetown Law Library. Posted with permission of the author. Follow this and additional works at: https://scholarship.law.georgetown.edu/facpub

Part of the Courts Commons, and the Sexuality and the Law Commons 


\section{GEORGETOWN LAW Faculty Publications}

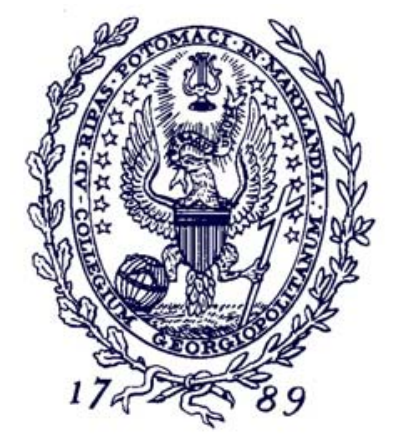

January 2010

\section{Sexual Orientation and the Paradox of Heightened Scrutiny*}

102 Mich. L. Rev. 1528-1554 (2004)

Nan D. Hunter

Professor of Law

Georgetown University Law Center

ndh5@law.georgetown.edu

This paper can be downloaded without charge from:

Scholarly Commons: http://scholarship.law.georgetown.edu/facpub/114/

Posted with permission of the author

*Reprinted from Michigan Law Review, June 2004, Vol. 102, No. 7. Copyright 2004 by Nan D.

Hunter. 


\title{
SEXUAL ORIENTATION AND THE PARADOX OF HEIGHTENED SCRUTINY
}

\author{
Nan D. Hunter*
}

In Lawrence $v$. Texas, ${ }^{1}$ the Supreme Court performed a double move, creating a dramatic discursive moment: it both decriminalized consensual homosexual relations between adults, and, simultaneously, authorized a new regime of heightened regulation of homosexuality. How that happened and what we can expect next are the subjects of this essay.

The obvious point of departure for an analysis of Lawrence is its decriminalization of much sexual conduct. Justice Scalia began this project with his dire warning that "[s]tate laws against bigamy, samesex marriage, adult incest, prostitution, masturbation, adultery, fornication, bestiality, and obscenity are ... sustainable only in light of Bowers' validation of laws based on moral choices."2 Justice Scalia correctly predicts that laws against fornication are now a dead letter; ${ }^{3}$ there are no laws against masturbation, so his worries there are unnecessary. ${ }^{4}$ But the judicial processes for evaluating laws prohibiting other sexual conduct will constitute one major segment of the overall process that will construct the next chapter of sexuality law.

Sodomy law operated as both a mechanism of subordination and a metaphor of heterosexual superiority. ${ }^{5}$ Decriminalization is not deregulation, however. Nor is it a marker of full equality. Rather, it is one stage in a regulatory process, one likely to produce even more "institutional incitement to speak about [sex], and to do so more and more; a determination on the part of the agencies of power to hear it spoken about, and to cause it to speak through explicit articulation

* Professor of Law, Brooklyn Law School. B.A., Northwestern University; J.D., Georgetown University Law Center. I appreciate the research assistance of Robin Fukuyama and Emily Kern, editorial suggestions by Anne Kanyusik of the Michigan Law Review, and the support of Brooklyn Law School's program of summer research stipends.

1. 123 S. Ct. 2472 (2003).

2. Lawrence, 123 S. Ct. at 2490.

3. See infra text accompanying notes 10-13.

4. Cass R. Sunstein, What Did Lawrence Hold? Of Autonomy, Desuetude, Sexuality, and Marriage, SUP. CT. REV. (forthcoming 2004), http://papers.ssrn.com/sol3/papers.cfm?abstract _id=450160 (Sept. 2003).

5. For an extensive analysis of the direct and indirect effects of sodomy law, see Christopher R. Leslie, Creating Criminals: The Injuries Inflicted by "Unenforced" Sodomy Laws, 35 HARV. C.R.-C.L. L. REV. 103 (2000). 
and endlessly accumulated detail."6 State involvement with sexuality has not ended, and Lawrence poses an implicit question: How will the discursive policing of homosexuality change in the wake of this decision? ${ }^{7}$

Legal disputes will likely center on the extent to which the indirect mechanisms operating in fields such as family and employment law will supplant criminal law in state regulation of homosexuality. Lawrence deprives the government of easy invocations of morals or tradition to justify regulation. Courts will have to engage in more particularized assessments of whether legitimate state interests justify classifications based on sexual orientation: judges will have to hear homosexuality spoken about even more frequently, and, in order to do their jobs, will have to cause it to speak.

The threshold question in such inquiries will be determining the correct standard of review. Courts may be reluctant to test sexual orientation classifications by the same stringent criteria that they apply under the upper tiers of Equal Protection review, but the extreme deference of old-fashioned rational basis review has now been complicated by the Court's recognition that at least some adverse treatment of gay people is invidious and disfavored. Justice O'Connor's concurring opinion suggests that there are two tiers of rational basis review as well, something the Court intimated but did not make explicit in Romer v. Evans. ${ }^{8}$

Whatever standard of review the courts apply, the inquiries into the reasonableness of differentiating based on sexual orientation will become more detailed and contextual. This aspect of "heightened scrutiny" reflects the fact that juridical discourse on sexuality always has two focuses: examination of the legitimacy of governmental actions and, often sub silentio, examination of the social acceptability of those persons who are the objects of the government's interventions. I use the phrase "heightened scrutiny" here to refer not to the standard hierarchy of levels of review under the Equal Protection Clause, but to surface this second, implicit meaning of the phrase. The paradox of this form of heightened scrutiny is that such

6. 1 Michel foucault, The History of SeXuality 18 (Robert Hurley trans., Vintage Books 1990) (1976).

7. Throughout this article, I refer solely to gay and lesbian persons, not to other sexual minorities, because homosexuality was the focus of the Court's opinion in Lawrence $v$. Texas. I expect, and hope, that transgendered people will also be able to invoke the Court's recognition that the government should not demean and disrespect its citizens based on harmless varieties of sexual self-representation. But a full explication of that set of issues is beyond the scope of this Article.

8. 517 U.S. 620 (1996); see also Civil Liberties for Urban Believers v. City of Chi., 342 F.3d 752, 768 (7th Cir. 2003) (Posner, J., dissenting) (" '[R]ationality' in the law of equal protection is not in fact a single standard, though the courts have been coy about admitting this."). 
examinations will constitute even greater state intrusion than occurred under the old criminal law regime, a development which seems the antithesis of the Lawrence Court's expansion of liberty.

\section{THE LAW OF LAWRENCE}

In Lawrence v. Texas, ${ }^{9}$ the Supreme Court struck down a Texas criminal statute that prohibited oral or anal sex between two persons of the same sex. In so doing, the Court held that the liberty interest protected by the Due Process Clause extends to adults "deciding how to conduct their private lives in matters pertaining to sex." it requires some effort to articulate precisely what standard of review the Court deployed in its analysis, ${ }^{11}$ there is no question that, whatever test it used, the Court eradicated the last vestiges of state power to criminalize private consensual adult sexual behavior solely on the basis of morality, without any showing of harm either to persons or to legally protected institutions.

To understand the extent to which the Court jettisoned morality qua morality as a legitimate justification, one can compare the decision in Lawrence to that of the Kentucky Supreme Court in Commonwealth $v$. Wasson, ${ }^{12}$ which also invalidated a law, essentially identical to the Texas statute, that prohibited sodomy only between same-sex partners. Relying on state constitutional provisions protecting liberty and equality, the Kentucky court did not bar legislative reliance on morality as a justification for criminalization of private adult consensual sexual conduct. Instead, the court held that a moral justification could only be legitimate if the same standard applied to all citizens, not just to lesbians and gay men. ${ }^{13}$ But the Kentucky court did not question the legitimacy of a morality justification for the prohibition of sodomy.

A holding such as that of the Kentucky court in Wasson - with its deference to legislated morality so long as it was evenhanded - was all that the Supreme Court in Lawrence had to adopt in order to strike down the Texas law. It is telling that the majority specifically

9. 123 S. Ct. 2472 (2003).

10. Id. at 2480 .

11. My view on this question is that a majority of the Court coalesced behind an approach described most elaborately in Justice Souter's concurring opinion in Washington $v$. Glucksberg, 521 U.S. 702, $752-89$ (1997) (Souter, J., concurring). See Nan D. Hunter, Living with Lawrence, 88 MINN. L. REV. 1103 (2004).

12. 842 S.W.2d 487 (Ky. 1992).

13. Wasson, 842 S.W.2d at $499-500$. Of course, for equality protections to be meaningful, even facially neutral statutes must be enforced and applied in a nondiscriminatory manner. 
eschewed this course. ${ }^{14}$ Instead, the Court rejected morality alone as a sufficient ground for prohibiting consensual sexual conduct.

Other opinions in Lawrence also undercut the morality defense. Justice O'Connor's concurring opinion, which did rely on Equal Protection grounds, rejected the most traditional use of morality rationales by noting that laws embodying moral disapproval of a group of persons could not pass a rational basis test. ${ }^{15}$ Even Justice Thomas's terse dissent, with its characterization of sodomy prohibitions as "uncommonly silly," suggested that he personally found the morality arguments unpersuasive, even though he believed that the judiciary was constrained not to second-guess a legislature's use of them. ${ }^{16}$

Thus, Lawrence proffers a critically important new principle: untethered to some objective, material referent, morality alone cannot justify deprivation of liberty. But exactly what this abstract declaration will mean in practice is anything but clear.

Most of the impact of the now extinct sodomy laws had already crossed the borders of criminal law prior to Lawrence. As the Court noted, criminalization invites "discrimination both in the public and in the private spheres." 17 Prior to Lawrence, courts had routinely accepted that invitation. Reasoning from the holding of Bowers $v$. Hardwick ${ }^{18}$ the judiciary developed what I have called the categorical inequality principle, ruling that because gay people presumptively violated criminal prohibitions against sodomy, the government could properly deny them employment or custody or visitation rights with their children. ${ }^{19}$

Categorical inequality based on sodomy laws has now ended. Despite the Court's strong rhetoric of respect and dignity as to gay lives ${ }^{20}$ however, the Lawrence opinion does not fully answer the equality question of when and under what circumstances the law must, to use Justice O'Connor's phrase, treat gay people "in the same manner as everyone else." 21

Instead, mixed in with the language of liberty, the Lawrence text contains a series of verbal gestures toward possibilities of regulation. In addition to a list of situations not covered by its holding, ${ }^{22}$ the Court

14. Lawrence, $123 \mathrm{~S}$. Ct. at 2480.

15. Id. at 2486 .

16. Id. at 2498 .

17. Id. at 2482 .

18. 478 U.S. 186 (1986).

19. Nan D. Hunter, Proportional Equality: Readings of Romer, 89 KY. L.J. 885, 893-95 (2000-01).

20. Lawrence, 123 S. Ct. at $2478,2482,2484$.

21. Id. at 2486 .

22. The Lawrence Court stated: 
in Lawrence explicitly left open the question of whether same-sex personal relationships are "entitled to formal recognition in the law."23 Consider the many aspects of family law, other than marriage, that courts deliberating on whether to accord "formal recognition in the law" to gay couples will have to address: eligibility for adoption, taxability of assets and income, immigration status, standing to seek redress for certain torts, entitlement to family leave and other employment benefits, and many others. Is "recognition" a positive or a negative liberty? If "formal recognition" entails some affirmative extension of benefits, can we infer that the liberty right precludes the imposition of penalties based on those relationships? If so, how does one draw the line between benefits denied and penalties imposed? Is there any disadvantage that the state can lawfully impose on noncommercial, consensual adult sexual conduct that occurs in private? ${ }^{24}$

It is striking that in the first year after the Lawrence majority authored the grand language of its opinion, appellate courts upheld three forms of stark antigay discrimination. In Standhart v. Superior Court of Maricopa County, ${ }^{25}$ the Arizona Court of Appeals ruled that the state could bar gay couples from marriage, on the ground that a rational relationship existed between the legal definition of marriage as limited to male-female unions and the state's legitimate interest in "ensuring responsible procreation within committed, long-term relationships." ${ }^{26}$ In State v. Limon, ${ }^{27}$ the Kansas Court of Appeals upheld a seventeen-year sentence for an eighteen-year-old male who engaged in oral sex with a fourteen-year-old male, despite the fact that the maximum sentence would have been slightly more than one year had one of them been female. In Lofton v. Secretary of Department of Children and Family Services, ${ }^{28}$ the U.S. Court of Appeals for the Eleventh Circuit upheld a Florida statute prohibiting gay people from adopting children, on the ground that the legislature could rationally decide that a policy favoring married couples and single heterosexuals furthered the state's goal of promoting healthy sexual development in children. Lawrence had surprisingly little impact on the outcome in

The present case does not involve minors. It does not involve persons who might be injured or coerced or who are situated in relationships where consent might not easily be refused. It does not involve public conduct or prostitution. It does not involve whether the government must give formal recognition to any relationship that homosexual persons seek to enter.

Id. at 2484 .

23. Id. at 2478 .

24. See infra Part II.

25. 77 P.3d 451 (Ariz. Ct. App. 2003).

26. Standhart, 77 P.3d at 463.

27. 83 P.3d 229 (Kan. Ct. App. 2004).

28. 358 F.3d 804 (11th Cir. 2004), reh'g denied, 377 F.3d 1275 (11th Cir. 2004). 
any of these decisions. Of the nine appellate judges who interpreted Lawrence in its first year, only one dissented from upholding these statutes. ${ }^{29}$

The importance of these particular rulings may fade with time; future courts may reject any or all of them. What is important is not what they stand for as propositions of law, but what they tell us about the possible limits of Lawrence. ${ }^{30}$ Their significance lies in how they exemplify the patterns and structure of the reasoning that courts may use in a post-sodomy-law world.

One pattern that these early cases illustrate is that because the concept of homosexuality as a benign variation has not yet achieved widespread cultural acceptance, the question of whether homosexuality actually causes harm in any given situation has no easy resolution. Gay-rights advocates and opponents will have to offer proof as to the existence of any asserted harms. ${ }^{31}$ Courts will decide fewer cases on motions to dismiss, and more litigation will involve factual disputes, although often concerning evidence of societal patterns as well as individualized situations. Contexts will vary widely, from those involving young children in the care of gay people, to anonymous or semi-anonymous sexual encounters, to individuals seeking positions of significant power or public esteem. In each context, courts will struggle with how to assess what role, if any, homosexuality should play in the official policies of the state or in the practices of private entities.

In the most significant victory for gay rights advocates since Lawrence, the Massachusetts Supreme Judicial Court in Goodridge v. Department of Public Health struck down that state's ban on marriage by same-sex couples. ${ }^{32}$ The court's majority ruled that the exclusion violates the state constitution as a matter of law. ${ }^{33}$ By contrast, two of the three dissents relied heavily on social science evidence regarding the effects on children of having been raised by same-sex partners, a body of research which they found inconclusive in establishing the absence of harm. ${ }^{34}$

29. Judge Pierron of the Kansas Court of Appeals dissented in Limon. 83 P.3d at 243 (Pierron, J., dissenting).

30. Similarly, the earliest post-Brown decisions are now forgotten. But they foretold subsequent flashpoints in the civil rights movement. See, e.g., Briggs v. Elliott, 132 F. Supp. 776, 777 (E.D.S.C. 1955) (interpreting Brown to mean that the Constitution "does not require integration [of public schools] .... It does not forbid such segregation as occurs as the result of voluntary action.").

31. Suzanne Goldberg characterizes this as the shift from philosophical to empirical bases for morality arguments. Suzanne B. Goldberg, Morals-Based Justifications for Lawmaking: Before and After Lawrence v. Texas, 88 MINN. L. REV. 1233 (2004).

32. 798 N.E.2d 941 (Mass. 2003).

33. Goodridge, 798 N.E.2d at 969.

34. Id. at 979-80, 998-99 \& nn.23-27. 
This is not to suggest that an intense engagement with facts operates to the disadvantage of equality advocates. In defending its law, Massachusetts relied on essentially the same arguments and kinds of proof as the state of Hawaii had used ten years earlier. On remand from the Hawaii Supreme Court, which ruled that the state had to demonstrate a compelling interest behind barring same-sex couples from marriage, ${ }^{35}$ evidence at trial focused on child-rearing practices and outcomes in gay families. ${ }^{36}$ The court ruled that the state had failed to satisfy its burden of proof ${ }^{37}$ With the debates over marriage likely to be replicated for years in various venues, we can expect to see such factual contests multiply. Indeed, with the elimination of morality alone as an acceptable legislative goal, both advocates for and opponents of marriage equality will intensify their focus on the construction of facts.

The result may be, certainly should be, far more victories by lesbian and gay litigants seeking equal rights and benefits in all these realms. However, the result will not be expanded liberty in the sense of less involvement by the state. The state, especially through its judicial and social service arms, will be more, not less, involved with the regulation of homosexuality. In each contested arena and even for each barrier to equality that falls, new principles will emerge to govern the relationship between the state and sexual orientation.

\section{THE PARADOX OF LAWRENCE}

The hidden message of Lawrence is that, despite the Supreme Court's proclamation of a zone of liberty "where the State should not be a dominant presence," 38 the role of the state in regulating homosexuality, both positively and negatively, will likely increase rather than decrease. As the early cases discussed in the preceding section indicate, assessing which state policies and private practices concerning homosexuality are lawful will require more, not less, judicial scrutiny. This new form of heightened scrutiny will entail more precise and detailed judicial inquiries into whether such policies and practices have legitimate justifications, beyond mere invocation of moral conventions.

One important effect of the categorical inequality principle characteristic of the Hardwick regime was that it eliminated the need

35. Baehr v. Lewin, 852 P.2d 44 (Haw. 1993). In 1998, however, the Hawaii Constitution was amended to empower the state legislature "to reserve marriage to opposite-sex couples." HAw. CONST. art. 1, § 23.

36. Baehr v. Miike, No. 91-1394, 1996 WL 694235, at *4-18 (Haw. Cir. Ct. Dec. 3, 1996).

37. Id. at *21.

38. 123 S. Ct. at 2475. 
to delve into those questions. A belief that homosexuality was properly subject to repression or de jure disadvantage reinforced the ideology of heterosexuality as both the natural and the normative ideal. Judicial reliance on categorical inequality precluded the contestation of that ideology. The enforcement of categorical inequality through the mechanism of highly deferential rational basis review rendered the constitutional validity of heterosexual privilege under law virtually inevitable. ${ }^{39}$ The absence of serious contestation allowed the policy choices behind a matrix of heteronormative laws to remain disguised as mere artifacts of natural law reasoning.

Lawrence is thus important less for its explicit protection of a private sphere of intimate decisionmaking than for its implicit unmasking of the interrelationship between sexuality and the state as a properly public sphere. The Court's repudiation of a morality justification was the rejection of assumed reasoning, of a rationale that need not speak its name. The legitimacy of a basis in morality for governmental efforts to control sexuality had been a given. ${ }^{40}$ Now those who would use the state as a mechanism for privileging heterosexuality must speak, and in some detail. The ensuing debate is likely to reveal the gap between "merely exempt[ing] [homosexual conduct] from criminal penalties" and "mak[ing] it "lawful in the full sense.' "

The law of adultery provides a good comparison. Laws in twentyfour states prohibit adultery, ${ }^{42}$ an offense that did not exist at common

39. See, e.g., High Tech Gays v. Def. Indus. Sec. Clearance Office, 895 F.2d 563, 571 (9th Cir. 1990); Ben-Shalom v. Marsh, 881 F.2d 454, 464-65 (7th Cir. 1989); Woodward v. United States, 871 F.2d 1068, 1076 (Fed. Cir. 1989); Watkins v. United States Army, 847 F.2d 1329, 1356-58 (9th Cir. 1988) (Reinhardt, J., dissenting), vacated en banc, 875 F.2d 699 (9th Cir. 1989); Padula v. Webster, 822 F.2d 97, 103 (D.C. Cir. 1987). The Supreme Court's decision in Romer v. Evans, 517 U.S. 620 (1996), mitigated this effect substantially, but not entirely. See Equal. Found. of Greater Cincinnati, Inc. v. City of Cincinnati, 128 F.3d 289 (6th Cir. 1997), cert. denied, 525 U.S. 943 (1998) (distinguishing a Cincinnati charter amendment on the ground that it did not affect statewide law and did not sweep as broadly as the Colorado state constitutional amendment invalidated in Romer v. Evans); Shahar v. Bowers, 114 F.3d 1097, 1110 (11th Cir. 1997) (en banc), cert. denied, 522 U.S. 1049 (1998) (distinguishing denial of a job as assistant state attorney general to a lesbian attorney on the ground that Romer v. Evans dealt with homosexuality as a status or condition, rather than conduct in violation of state law).

40. Barnes v. Glen Theatre, Inc., 501 U.S. 560, 569 (1991) (plurality opinion); Bowers v. Hardwick, 478 U.S. 186, 196 (1986); King v. Smith, 392 U.S. 309, 320-27 (1968) (specific federal policy limits state's power to discourage immorality); Williams v. Pryor, 240 F.3d 944, 949 (11th Cir. 2001).

41. JeFFrey WeEks, SeX, Politics and SOCIETy: The Regulation of SEXUALITY SINCE 1800, at 275 (1981).

42. See Ala. Code § 13A-13-2 (1982); ARIZ. REv. STAT. ANN. §§ 13-1408-09 (West 2001); COLO. REV. STAT. ANN. § 18-6-501 (West 2003); FLA. STAT. ch. 798.01 (2003); GA. CODE ANN. \& 16-6-19 (2003); IDAHO CODE \$ 18-6601 (Michie 2004); 720 ILL. COMP. STAT. 5/11-7 (2002); KAN. STAT. ANN. \$ 21-3507 (1995); MD. CODE ANN., Criminal Law \$ 10-501 (2002); MASS. GEN. LAwS ch. 272, \$14 (2002); MICH. COMP. LAwS § 750.29-.30 (1979); MINN. STAT. $§ 609.36$ (1982); MISS. CODE ANN. \$ 97-29-1 (2000); N.H. REV. STAT. ANN. $§ 645: 3$ 
law but arose from the religious and moral beliefs of Europeans who settled the American colonies. ${ }^{43}$ Virtually no prosecutions have occurred for the last quarter century, except in cases also involving a charge of rape. ${ }^{44}$ Moreover, the history of adultery law reveals that non-prosecution is more than simply desuetude; a longstanding ambivalence continues over whether adultery laws should police only "open and notorious" conduct so as to prevent public scandal, but overlook private infidelity. ${ }^{45}$

From the combination of repeal, inapplicability, and disuse, criminal laws against adultery have essentially become a dead letter. Thus, although one can argue about whether the Court's holding in Lawrence requires invalidating them as a constitutional matter, prohibitions of adultery have already become functionally irrelevant as the basis for direct criminal prosecution. That does not mean, however, that adultery has become "lawful in the full sense."

Instead, legal regulation of adultery serves many of the same functions that sodomy law has served: imposing penalties through the operation of civil law, facilitating private discrimination, and solidifying social and cultural norms. The state continues to regulate adultery in a somewhat ad hoc fashion in multiple venues: through employment law, ${ }^{47}$ family law, ${ }^{48}$ and tort law. ${ }^{49}$ In each zone, courts

(1996); N.Y. PENAL LAW § 255.17 (McKinney 2000); N.C. GEN. STAT. ANN. § 14-184 (Michie 2003); N.D. CENT. CODE ANN. \$ 12.1-20-09 (Michie 1997); OKLA. STAT. ANN. tit. 21, § 871 (West 2002); R.I. GEN. LAwS ANN. § 11-6-2 (Michie 2002); S.C. CODE ANN. § 16-15-60, -70 (Law. Co-op. 2003); UTAH CODE ANN. § 76-7-103 (2003); VA. CODE ANN. § 18.2-365 (Michie 1996); W. VA. CODE ANN. \$ 61-8-3 (Michie 2000); WIS. STAT. § 944.16 (2002).

43. Martin J. Siegel, For Better or for Worse: Adultery, Crime \& the Constitution, $30 \mathrm{~J}$. FAM. L. 45, 47-49 (1991-92); Jeremy D. Weinstein, Note, Adultery, Law, and the State: A History, 38 HASTINGS L.J. 195, 210, 212-26 (1986).

44. There are only four reported cases in the last twenty-five years involving criminal prosecutions for adultery, in which an allegation of rape was not involved. See State v. Mangon, 603 So. 2d 1131 (Ala. Crim. App. 1992); Commonwealth v. Stowell, 449 N.E.2d 357 (Mass. 1983); Van Norman v. State, 365 So. 2d 644 (Miss. 1978); Commonwealth v. Papariella, 439 A.2d 827 (Pa. Super. Ct. 1982). Press reports exist of other cases. Note, Constitutional Barriers to Civil and Criminal Restrictions on Pre-and Extramarital Sex, 104 HARV. L. Rev. 1660, 1672 n.88 (1991); John F. Kelly, Va. Adultery Case Roils Divorce Industry, WASH. POST, Dec. 1, 2003, at B1. Nonetheless, overall direct enforcement appears to be minimal, at least outside the military. See infra text accompanying notes 71-76.

45. See Morris Ploscowe, SEX AND THE LAW 150-53 (1951) (discussing Warner $v$. State, 175 N.E. 661 (Ind. 1931), and State v. Chandler, 33 S.W. 797 (Mo. 1896)). Currently, statutes in Alabama, Florida, Illinois, North Carolina and Oklahoma require openness or cohabitation. See statutes cited supra note 42.

46. Knuller, Ltd. v. Dir. of Public Prosecution, 1973 A.C. 435, 457 (1972) (upholding conviction for conspiracy to corrupt public morals for publication of gay male personal ads).

47. See infra text accompanying notes 58-70.

48. See, e.g., Mabus v. Mabus, No. 2001-CA-00381-SCT, 2003 WL 327669 (Miss. Feb. 13, 2003); In re Blanchflower, 834 A.2d 1010 (N.H. 2003); R.G.M. v D.E.M., 410 S.E.2d 564 (S.C. 1991); Shackelford v. Shackelford, 571 S.E.2d 917 (Va. Ct. App. 2002). See generally 
have analyzed the functions served by various legal principles that produce disadvantage for married persons who engage in sexual relations with persons other than their spouses. Moral justifications have sometimes figured in these decisions; ${ }^{50}$ Lawrence has rendered those justifications insufficient standing alone. But morality accounts for only some of a variety of rationales that courts have examined.

Consider the parallels to sodomy law, especially in the realm of the workplace. When gay-rights advocates asserted that sodomy laws indirectly created employment-law penalties, they often pointed to a series of cases in which openly gay persons were denied jobs in some aspect of law enforcement. In these cases, the state agencies argued, and prevailed on, a theory that persons who admittedly violated the state's sodomy law were not fit to be hired as police officers or state's attorneys. ${ }^{51}$ Robin Shahar, for example, was denied employment as an assistant state attorney general in Georgia on the ground that her participation in a religious marriage ceremony marked her as someone likely to engage in sodomy, then a crime in Georgia, and whose presence would create credibility and public perception problems for the Attorney General. The Eleventh Circuit ruled that Attorney General Michael Bowers was justified in rescinding her job offer on those grounds. ${ }^{52}$ Ironically, it later came to light that Bowers himself had been engaging in an adulterous relationship with a woman who worked in his office at the time he refused to hire Shahar. ${ }^{53}$

Today, sodomy is no longer a crime in Georgia. ${ }^{54}$ Adultery, however, remains illegal. ${ }^{55}$ If Bowers (who left office to run for governor) were to apply for a job in his old office, would he be barred from employment? If Shahar were to re-apply, would she finally get

JOHN C. MAYONE, BALANCING COMPETING INTERESTS IN FAMILy LAW 8 (2d ed. 2003); Note, supra note 44.

49. See, e.g., Bland v. Hill, 735 So. 2d 414 (Miss. 1999); Norton v. Macfarlane, 818 P.2d 8 (Utah 1991). See generally Note, supra note 44.

50. Linda Fitts Mischler, Personal Morals Masquerading as Professional Ethics: Regulations Banning Sex Between Domestic Relations Attorneys and Their Clients, 23 HARV. WOMEN'S L.J. 1, 23-25, 42-44 (2000). 02-102).

51. Brief for Petitioners at 42-43, Lawrence v. Texas, 123 S. Ct. 2472 (2003) (No.

52. Shahar v. Bowers, 114 F.3d 1097 (11th Cir. 1997) (en banc), cert. denied, 522 U.S. 1049 (1998).

53. Kevin Sack, Georgia Candidate for Governor Admits Adultery and Resigns Commission in Guard, N.Y. TIMES, June 6, 1997, at A29. The Eleventh Circuit refused to supplement its record by either taking judicial notice of Bowers's admission or by permitting further discovery, in part because "we cannot readily say that the result of the case probably would be different." Shahar v. Bowers, 120 F.3d 211, 214 (11th Cir. 1997).

54. The Georgia Supreme Court found that the sodomy statute violated the state constitution's protection of privacy. Powell v. State, 510 S.E.2d 18 (Ga. 1998).

55. GA. CODE ANN. §16-6-19 (2003). 
the job? The answers are not as clear as one might think. In an ironic result of Lawrence, Bowers seems in the weaker position: unlike Shahar, he has admitted to the commission of a crime..$^{56}$

In contrast to the near absence of reported decisions in prosecutions for adultery, a small but distinct body of jurisprudence has arisen from analysis of the proper relationship between sexual conduct outside marriage and fitness for public employment. Two U.S. Court of Appeals rulings exemplify the uncertainty in this area. These decisions, which concern actions taken fifteen years apart, hold that government officials enjoy immunity from suits by public employees on the ground that there is no clear answer to the question of whether the state can regulate private, off-duty sexual behavior..$^{57}$

Case law in the Sixth Circuit best illustrates the trajectory of the public employment and adultery litigation. Prior to Bowers $v$. Hardwick, the court upheld without opinion a district court decision ruling that a police force could not fire a male officer for cohabiting with a woman when both were married to someone else. ${ }^{58}$ Justice White dissented from the denial of certiorari in the case, arguing that the Supreme Court needed to determine the constitutionality of restrictions on adult consensual sexual activity. ${ }^{59}$ Two years earlier, dissenting from denial of review in a similar Fifth Circuit case, Justice Brennan noted that "lower courts have divided sharply both in their results and in their analytic approach" to the question, which he argued the Court should answer by recognizing a fundamental right. ${ }^{60}$

After Hardwick, courts in the Sixth Circuit relied on the categorical-inequality principle to rule that no constitutional protection attended an intimate adulterous relationship because such intimacy cannot be said to be either "deeply rooted in the Nation's

56. Shahar, however, would not automatically be home free, since Bowers's theory of his case in defending her firing was that her religious marriage ceremony signaled her violation of Georgia's marriage statute as well as its sodomy law. See 114 F.3d at 1111 (Tjoflat, J., concurring).

57. Hughes v. City of N. Olmsted, 93 F.3d 238, 241-42 (6th Cir. 1996) (immunity from liability for investigation of whether police officer had "open marriage"); Thorne v. City of El Segundo, 802 F.2d 1131, 1138-40 (9th Cir. 1986) (immunity from liability for broad inquiry into employee's off-duty sexual activities).

58. City of N. Muskegon v. Briggs, 746 F.2d 1475 (6th Cir. 1984), cert. denied, 473 U.S. 909 (1985).

59. 473 U.S. at $909-10$ (White, J., dissenting from denial of cert.). Justice White's recognition that the law was unsettled as to the permissibility of criminal prohibitions on consensual adult heterosexual conduct makes his decision in Bowers v. Hardwick even stranger. Because the Georgia statute at issue there applied to heterosexual as well as homosexual acts, White had the opportunity that he had sought a year earlier to clarify the law. Instead, his opinion reads as an anti-gay polemic.

60. Whisenhunt v. Spradlin, 464 U.S. 965, 965-66, 971-72 (1983) (Brennan, J., dissenting). 
history and tradition or implicit in the concept of ordered liberty."61 One judge, however, argued that the court should examine the facts of any given case in light of the factors the Supreme Court identified in Roberts $v$. United States Jaycees ${ }^{62}$ as indicative of an intimate association entitled to constitutional protection. ${ }^{63}$ Those factors include depth of emotional attachment, degree of commitment, selectivity, and the sharing of "distinctively personal aspects of one's life."64 Judge Clay's concurrence provides a good example of the alternate meaning of heightened scrutiny that I am using: in the process of applying a more stringent standard of review which accorded more respect to the plaintiff's adulterous relationship than the majority's use of a per se rule, he subjected the relationship to a detailed factual examination, eventually concluding that it lacked the indicia of intimacy that the Supreme Court had identified in Roberts. ${ }^{65}$ One result of Lawrence may be more viable claims of intimate association rights by same-sex couples, leading to the same degree of judicial inquiry.

The adultery and public employment cases demonstrate that the question of allowable penalty in such cases remains complex. In some cases, the public knew of the employee's conduct, raising the question of whether it adversely affected the standing of the law-enforcement agency with the public. ${ }^{66}$ Cases also vary as to whether the adulterous relationship involved a co-worker ${ }^{67}$ or the spouse of a co-worker ${ }^{68}$ In other cases, the relationship concerned persons who had come to the attention of the law-enforcement agency because of some link to other criminal activity. ${ }^{69}$ The presence or absence of a criminal prohibition

61. Marcum v. McWhorter, 308 F.3d 635, 642 (6th Cir. 2002); see also Mercure v. Van Buren Township, 81 F. Supp. 2d 814 (E.D. Mich. 2000). Courts outside the Sixth Circuit also relied on Hardwick's categorical reasoning. Oliverson v. W. Valley City, 875 F. Supp. 1465, 1482-83 (D. Utah 1995); City of Sherman v. Henry, 928 S.W.2d 464, 470-72 (Tex. 1996).

62. 468 U.S. 609 (1984).

63. 308 F.3d at 643-46 (Clay, J., concurring).

64. Roberts, 468 U.S. at 619-20; Bd. of Dirs. of Rotary Int'l v. Rotary Club, 481 U.S. 537, 546 (1987).

65. 308 F.3d at 645-46.

66. Suddarth v. Slane, 539 F. Supp. 612 (W.D. Va. 1982); Wilson v. Swing, 463 F. Supp. 555 (M.D.N.C. 1978); Cook v. South Carolina Dep't of Highways \& Pub. Transp., 420 S.E.2d 847 (S.C. 1992); see also Hollenbaugh v. Carnegie Free Library, 578 F.2d 1374 (3d Cir. 1978), cert. denied, 439 U.S. 1052 (1978) (librarians).

67. Shawgo v. Spradlin, 701 F.2d 470 (5th Cir. 1983); Johnson v. San Jacinto Junior Coll., 498 F. Supp. 555 (S.D. Tex. 1980); Wilson, 463 F. Supp. 555 (M.D.N.C. 1978).

68. City of Sherman v. Henry, 928 S.W.2d 464 (Tex. 1996).

69. Baron v. Meloni, 556 F. Supp. 796 (W.D.N.Y. 1983). 
per se cannot resolve any of the workplace-management problems that these scenarios raise. ${ }^{70}$

Federal law governing members of the armed services has codified these considerations into a set of provisions that function as one integrated combination of criminal law and employment code. Articles 133 and 134 of the Uniform Code of Military Justice permit prosecutions for adultery ${ }^{71}$ as constituting either "conduct unbecoming an officer and a gentleman" 72 or an action that is "to the prejudice of good order and discipline in the armed forces" or "of a nature to bring discredit upon the armed forces." 73 By Executive Order in 2002, however, President Bush sharply curtailed the effective reach of the U.C.M.J. The Bush Executive Order revised the Manual for Courts Martial to define prejudice to good order as "conduct that has an obvious, and measurably divisive effect on unit or organization discipline, morale or cohesion, or is clearly detrimental to the authority or stature of or respect toward a servicemember." "It further limited service-discrediting conduct to that which was "open and notorious." 75 In addition, the Order specified factors that military authorities must consider before initiating a court martial, including the respective ranks of the "accused" and the "co-actor," the connection, if any, between the spouse(s) and the military, the impact on any member's own job performance, and any misuse of "government time and resources to facilitate the commission of the conduct." $" 76$

The law of adultery and public employment offers a preview of the kinds of inquiries that are likely to arise in judicial scrutiny of homosexuality and employment after Lawrence. With the decisive effect of criminalization removed, courts will have to ask more, not fewer, questions about the nexus between the sexual activity at issue and the workplace. One could even imagine the open and notorious

70. Some cases arose in jurisdictions without a criminal prohibition of adultery. Hollenbaugh, 439 U.S. at 1057 (Marshall, J., dissenting from denial of cert.); Marcum v. McWhorter, 308 F.3d 635, 642 (6th Cir. 2002).

71. C. Quince Hopkins, Rank Matters But Should Marriage?: Adultery, Fratenerization, and Honor in the Military, 9 UCLA WOMEN'S L.J. 177, 213-34 (1999); see, e.g., United States v. Kroop, 38 M.J. 470 (C.M.A. 1993); United States v. Frazier, 34 M.J. 194 (C.M.A. 1992).

72. 10 U.S.C. $\$ 933(2000)$.

73. 10 U.S.C. $\S 934(2000)$.

74. Exec. Order No. 13262, 3 C.F.R. 210 (2003), (amending Exec. Order No. 12473, 3 C.F.R. 201 (1985)). The Executive Order partially implements one of the recommendations of a panel sponsored by the National Institute for Military Justice, which recommended full decriminalization of both adultery and sodomy. Report of the Commission on the 50th Anniversary of the Uniform Code of Military Justice (May 2001), at www.badc.org/html/militarylaw_cox.html.

75. 3 C.F.R. at 217.

76. Id. 
standard from the Bush Executive Order on adultery replacing the military's Don't Ask Don't Tell policy.

Just as civil penalties for sexual harassment have led to the generation of hundreds of judicial narratives about the details of sexual interactions in the workforce, the need to regulate how employers can or cannot take sexual orientation into consideration will intensify the law's discourse on homosexuality. Indeed, with the Supreme Court's ruling that same-sex sexual harassment can be actionable if the discriminatory conduct occurred because of the sex of the person harassed ${ }^{77}$ the process of examining harassment with homosexual overtones has already begun. In its opinion, the Court was careful to specify an exemption for "intersexual flirtation" from the zone of objectionable activity, ${ }^{78}$ leaving lower courts to infer that same-sex flirtation might be judged differently. One court has noted that it "cannot rule out that the homosexual aspect of harassment could objectively contribute [to] a hostile environment.",79

\section{CONTAINMENT AND COMPLEXITY}

As is true in both the adultery employment law cases and the earliest round of post-Lawrence sexual orientation cases, courts provide a central institutional venue for negotiating the role of sexuality in the public sphere. Even the autonomy claims specifically denominated as privacy and associated with contraception and abortion always spilled outside the private sphere. Efforts to establish the public presence of birth control clinics, not any real threat of police in the bedroom, triggered the series of lawsuits eventually resulting in Griswold v. Connecticut and the Supreme Court's recognition of privacy as a component of substantive due process. ${ }^{80}$ Lawrence secures the right to seclusion and shelter for sexual intimacy, but its impact on full sexual autonomy beyond the operation of criminal law is much less clear.

The question of social legitimacy marks the cultural fault line for homosexuality, the point at which political eruptions occur. Given the intensity of debates over such issues as marriage, it seems unlikely that genuine, consistent moral neutrality will characterize social and legal

77. Oncale v. Sundowner Offshore Servs., Inc., 523 U.S. 75 (1998).

78. Id. at 81 .

79. Miller v. Vesta, Inc., 946 F. Supp. 697, 712-13 (E.D. Wis. 1996).

80. 381 U.S. 479 (1965). All of the Connecticut litigation grew from the closure of birth control clinics in 1940. DAVID J. GARROW, LIBERTY \& SEXUALITY: THE RIGHT TO PRIVACY AND THE MAKING OF ROE $V$. WADE 60-72 (1994). Two federal court challenges prior to Griswold were dismissed on standing and ripeness grounds: Tileston v. Ullman, 318 U.S. 44 (1943), and Poe v. Ullman, 367 U.S. 497 (1961). For an early (and critical) observation of the problems with the term "privacy," see Richard A. Posner, The Uncertain Protection of Privacy by the Supreme Court, 1979 SUP. CT. REV. 173. 
practices related to homosexuality in the near future. Rather, deprived of criminal law as a tool, opponents of equality for lesbians and gay men are likely to concentrate increasingly on the strategy of containment.

The effort to contain homosexuality and even an explicit comparison to communicable disease is not new; even before AIDS, the metaphor of disease was used to defend sodomy laws. ${ }^{81}$ Containment now buttresses a kinder, gentler hierarchy, but one that courts nonetheless continuously modernize by refining the rationales for antigay bigotry. ${ }^{82}$ Much of the current debate about homosexuality appears grounded in beliefs in fair treatment for lesbian and gay Americans that co-exist with beliefs in the superiority of heterosexuality. ${ }^{83}$ In this atmosphere, public policy disputes are likely to center on the proper degree of containment necessary for what is perceived to be the homosexual menace to public culture. Drawing on archetypes of danger long associated with homosexuality, ${ }^{84}$ three themes or discursive fields are likely to emerge as the primary arenas for regulation and scrutiny: situation-specific disputes involving children or the control of expressive space; the rank ordering of samesex relationships into legal hierarchies; and containment by analogy.

\section{A. Situation-Specific Containment}

\section{Children}

Lofton v. Secretary of Department of Children and Family Services $^{85}$ and State $v$. Limon ${ }^{86}$ both illustrate the power of containment arguments in contexts involving children. Both cases reflect the mixture of pre- and post-Lawrence paradigms at work in

81. Ratchford v. Gay Lib, 434 U.S. 1080, 1084 (1978) (Rehnquist, J., dissenting from denial of cert.).

82. William N. Eskridge JR. \& Nan D. Hunter, Sexuality, Gender, and THE LAW 1177-78 (2d ed. 2004); William N. Eskridge, Jr., No Promo Homo: The Sedimentation of Antigay Discourse and the Channeling Effect of Judicial Review, 75 N.Y.U. L. REV. 1327 (2000).

83. Charles Lane, Polls: Americans Say Court Is "About Right," WASH. POST, July 7, 2003, at A15; James Ricci \& Patricia Ward Bierderman, Acceptance of Gays on Rise, Polls Show, L.A. TimeS, Mar. 30, 2004, at B1; Katharine Q. Seelye \& Janet Elder, Strong Support is Found for Ban on Gay Marriage, N.Y. TIMES, Dec. 21, 2003, at A1.

84. Larry Catá Backer has described how decades of case law prior to Lawrence helped to construct the image of gay men as seducers of youth, sexually promiscuous, defilers of public space, and predators. Larry Catá Backer, Constructing a "Homosexual" for Constitutional Theory: Sodomy Narrative, Jurisprudence, and Antipathy in United States and British Courts, 71 TUL. L. REV. 529 (1996); see also Nancy J. Knauer, Homosexuality as Contagion: From The Well of Loneliness to the Boy Scouts, 29 HOFSTRA L. REV. 401 (2000) (tracing the history of the contagion and identity models of homosexuality).

85. 358 F.3d 804 (11th Cir. 2004).

86. 83 P.3d 229 (Kan. Ct. App. 2004). 
particularly vivid ways, because both were structured and litigated at the trial court level and through initial appeals prior to the Court's decision in Lawrence. Limon was pending before the Supreme Court on a petition for certiorari when Lawrence was decided; the Court remanded so that the Kansas Court of Appeals could reconsider its earlier decision upholding differential sentencing in light of Lawrence $^{87}$ The Eleventh Circuit heard oral argument in Lofton before the Lawrence opinion issued, and received supplemental briefs from the parties afterward ${ }^{88}$ Thus, in both cases, the parties and the court had to adjust when Bowers v. Hardwick was overruled.

Limon involved consensual oral sex between two males, fourteenand eighteen-years-old, both residents in a facility for the developmentally disabled. Kansas criminalized same-sex sodomy at the time, but, in this instance, had one participant been female, there still would have been a prosecutable offense, because the law presumed the fourteen-year-old could not consent. The statute governing sentencing created a special category, however, when two opposite-sex participants were less than four years apart in age. Under that statute, Matthew Limon would have received a sentence of thirteen to fifteen months in prison had the other party been female. Instead, because the "Romeo and Juliet" provision explicitly excluded same-sex partners, he received a sentence of seventeen years and two months. ${ }^{89}$

The Lofton plaintiffs challenged a Florida statute that prohibited adoption by persons "known to engage in current, voluntary homosexual activity," then illegal under that state's sodomy law. ${ }^{90}$ Florida allowed both married couples and single heterosexuals to adopt children. ${ }^{91}$ The plaintiffs included gay foster parents and legal guardians who sought to adopt the children for whom they had been caring. ${ }^{92}$

Prior to Lawrence, attorneys for Kansas had defended its statute by arguing the categorical principle of Hardwick: if the state could constitutionally criminalize homosexual sexual behavior, it could also impose differential punishment upon persons who engaged in that behavior. ${ }^{93}$ Attorneys for Florida had invoked morality as a rational

87. Limon v. Kansas, 123 S. Ct. 2638 (2003).

88. Lofton, 358 F.3d at 809 .

89. State v. Limon, 83 P.3d 229 (Kan. Ct. App. 2004).

90. The statute states, "No person eligible to adopt under this statute may adopt if that person is a homosexual." FLA. STAT. ch. 63.042(3) (2003). Courts subsequently developed the definition of "homosexual." See Lofton, 358 F.3d at 807.

91. FLA. STAT. ch. 63.042(2)(a)-(b) (2003).

92. Lofton, 358 F.3d at 807-08.

93. Limon, 83 P.3d at 244 (Pierron, J., dissenting). 
basis for differential treatment under the Equal Protection Clause. ${ }^{94}$ Despite Lawrence, neither state relinquished a morality claim, ${ }^{95}$ and both courts accepted the goal of shielding children from exposure to homosexuality as a legitimate substitute for the morality argument rejected in Lawrence.

The Eleventh Circuit buried the state's earlier justification of morality in a footnote as if it had never been significant, ${ }^{96}$ and found that the state could rationally conclude that the "presence of both male and female authority figures [was] critical to optimal childhood development and socialization." ${ }^{97}$ As the reason for why that statement would be true, the court stated that "heterosexual singles, even if they never marry, are better positioned than homosexual individuals to provide adopted children with education and guidance relative to their sexual development throughout pubescence and adolescence." ${ }^{18}$ On this reasoning, homosexuality intrinsically presents possible harm to children, and the state in exercise of its solemn duty to protect children in its care, can act to prevent that harm from occurring.

On a six to six vote, the Eleventh Circuit denied rehearing en banc..$^{99}$ Dissenting from that order, Judge Barkett argued that the court should not assume that such harm would occur, and complained that "the panel never explains why it is rational to believe that homosexuals, as a class, are unable to provide stable homes and appropriate role models for children." 100 Judge Birch, in his special concurrence, sought to answer: "[T]he mainstream of contemporary American family life consists of heterosexual individuals. Can it seriously be contended that an arguably rational basis does not exist for placing adoptive children in the mainstream of American family life?"101 Judge Birch's response still fails to furnish an explanation, but as the exchange framed here by Judges Barkett and Birch continues, either in this case or in future cases, the arguments are likely to grow more specific.

94. Lofton v. Kearney, 157 F. Supp. 1372, 1382 (S.D. Fla. 2001); Brief of Appellees at 41-47, Lofton v. Sec'y of the Dep't of Children and Family Servs., 358 F.3d 804 (11th Cir. 2004) (No. 01-16723).

95. Appellee's Brief on Rehearing at 15-20, State v. Limon, 32 Kan. App. 2d 369 (2004) (No. 00-85898-A); Lofton v. Sec'y of the Dep't of Children and Family Servs., 358 F.3d at 819 n.17; Lofton v. Sec'y of the Dep't of Children and Family Servs., 377 F.3d 1275, 1278 (11th Cir. 2004) (en banc).

96. Lofton, 358 F.3d at 819 n.17.

97. Id. at 818.

98. Id. at 822 .

99. 377 F.3d 1275 (11th Cir. 2004).

100. 377 F.3d at 1298 .

101. Id at 1276. 
In Limon, containment functioned as the basis for upholding the sentencing differential, literally for the justice who wrote the primary opinion and metaphorically for the concurring justice. Justice Green, writing for the court, is a Lawrence resister: he refuses to surrender morality as a basis for imprisonment. Among the variety of rationales he offered to explain why the legislature would impose such a draconian differential, Justice Green included "to prevent the gradual deterioration of the sexual morality approved by a majority of Kansans." 102 Justice Malone, concurring, demurred from following that path, but accepted that it would be reasonable for the legislature to protect children from the "increased health risks associated with homosexual activity until they are old enough to be more certain of their choice." ${ }^{103}$ Remarkably, he found this reason persuasive despite his acknowledgment that no increased health risks ensue when the participants in a homosexual act are female. ${ }^{104}$

We expect adults to protect themselves from pernicious influences and obvious dangers, but society steps in to protect children when necessary. Both Lofton and Limon involved minors in the custody of the state, eliminating any potential conflict between state and parent. Even before Lawrence, an overwhelming shift in family law had resulted in the protection of the custody and visitation rights of gay parents and even the institutionalization of two-parent adoption by gay couples. In jurisdictions where that has not occurred, however, the future battles will center on arguments of containment in the form of protecting children from the harmful effects of exposure to homosexuality.

\section{Expressive Space}

Geography created an important limiting principle in Lawrence by specifying a key spatial dimension - private space - to the liberty being protected. ${ }^{105}$ The opposite spatial dimension - public space, with its openness to representation and advocacy - presents a different critical question for the law: to what extent, if any, can the state regulate public culture, where exposure to homosexuality is most likely and thus containment arguably most urgently needed?

Sexual speech of any sort has led to the First Amendment anomaly of courts according public speech less protection than private speech, and allowing the government to zone explicit representation into

102. Limon, 83 P.3d at 236.

103. Id. at 242 (Malone, J., concurring).

104. Id.

105. Lawrence, $123 \mathrm{~S}$. Ct. at 2484. 
certain locations and out of others. ${ }^{106}$ So we begin from the proposition that sexual speech is different from and less valued under the law than other speech. Will homosexual sexual speech be more different still, accorded less protection than heterosexual sexual speech? And could that possibly be true now, even if such a differential was permissible prior to Lawrence? Put another way, if homosexual conduct is legal, how could homosexual speech be penalized? ${ }^{107}$

Some limits on when gay speech can be suppressed are clear. At least the second half of "don't ask, don't tell" used to be the cultural norm, but is no longer; media representations of homosexuality and out gay people are commonplace. ${ }^{108}$ A partial exception to this persists in schools, where the degree of openness is largely left to administrative discretion, ${ }^{109}$ and in electronic and interactive media, where courts await maturation of filtering and other technologies that facilitate parental control. ${ }^{110}$

Propositioning an adult of the same sex in a public space to engage in conduct in a private space ought to be insulated from prosecution because it is a solicitation to commit a lawful act. However, the Oklahoma Court of Criminal Appeal stated in 1995 in a case involving two men that solicitation even for private lawful conduct could be prosecuted: "the solicitation of some sexual acts is simply not appropriate in public places. To suggest that government cannot prohibit such solicitation is unfathomable."111 No Oklahoma court has yet ruled on whether this dicta will survive Lawrence, but the court's reasoning indicates that the distinction between public and private space remains a viable one in First Amendment jurisprudence on sexual speech.

Insofar as explicit representation is concerned, the law is thoroughly muddled and likely to remain so. In this area, the law, like the imagery, is unruly; cases involve varying degrees of erotic content,

106. City of L.A. v. Alameda Books, 535 U.S. 425 (2002).

107. I do not address issues related to the military's Don't Ask, Don't Tell policy, which is now more vulnerable under a First Amendment analysis.

108. See generally SuZANna DaNUTA WALters, All THE RAGE: THE StORY OF GAY VISIBILITY IN AMERICA (2001).

109. See, e.g., Boring v. Buncombe County Bd. of Educ., 136 F.3d 364 (4th Cir. 1998) (en banc) (upholding transfer of teaching for violating policy against presenting "controversial materials" to students); Brown v. Hot, Sexy and Safer Productions, Inc., 68 F.3d 525 (1st Cir. 1995) (finding that mandatory AIDS awareness assembly did not create hostile environment).

110. ACLU v. Ashcroft, 124 S. Ct. 2783 (2004) (affirming injunction against federal Child Online Protection Act); United States v. American Library Ass'n, 123 S. Ct. 2297 (2003) (upholding requirement that public library install filters on computers in order to qualify for federal funds).

111. Sawatzky v. City of Oklahoma City, 906 P.2d 785, 787 n.7 (1995). 
in contexts ranging from health education ${ }^{112}$ to high art ${ }^{113}$ to unadorned commerce. At least as a matter of law, the elimination of sodomy statutes will not change much, and Lawrence is unlikely to prevent wide discrepancies in the law affecting containment of homosexual imagery in public space.

Most public space containment cases still involve an older discursive theme of the uniquely offensive character of homosexual expression, but a more modern theme also exists, that of suppressing gay speech to prevent disruption or even violence. The military's don't ask, don't tell policy is founded on this argument, expressed as the unit cohesion rationale, ${ }^{114}$ and examples of it exist outside that institution as well. ${ }^{115}$

\section{B. Containment by Hierarchy}

The rhetoric of respect for gay relationships in Lawrence, combined with a myriad of other forms of legal recognition for samesex couples, signals that the period when such couples were treated as strangers under the law is over. Even states with sodomy laws that were in effect up until the Court's decision in Lawrence contained municipalities that recognized gay couples for some purposes. ${ }^{116}$ Indeed, current debate over relationships centers on what, until

112. Hot, Sexy and Safer Productions, Inc., 68 F.3d 525 (1st Cir. 1995); Gay Men's Health Crisis v. Sullivan, 792 F. Supp. 278 (S.D.N.Y. 1992) (invalidating CDC policies regarding AIDS educational materials as contrary to statutory standard and void for vagueness); Rees v. State, 909 S.W.2d 264 (Tex. Ct. App. 1995) (upholding obscenity conviction for showing film of sex acts between men on public access cable sex information program).

113. National Endowment for the Arts v. Finley, 524 U.S. 569 (1998) (upholding statutory requirement that NEA consider "general standards of decency" in making grant awards).

114. See, e.g., Thomasson v. Perry, 80 F.3d 915, 929-30 (4th Cir. 1996) (en banc).

115. The same rationale of treating men's sexual solicitation of other men as constituting provocation of violence lay behind acceptance of the "gay panic" defense. See Joshua Dressler, When "Heterosexual" Men Kill "Homosexual" Men: Reflections on Provocation Law, Sexual Advances, and the "Reasonable Man" Standard, 85 J. CRIM. L. \& CrIminology 726, 754-56 (1995); Christina Pei-Lin Chen, Note, Provocation's Privileged Desire: The Provocation Doctrine, "Homosexual Panic," and the Non-Violent Unwanted Sexual Advance Defense, 10 CORNELL J.L. \& PUB. POL'Y 195 (2000). Ohio recently reversed case law in which same-sex solicitation was criminalized under a "fighting words" rationale, on the theory that a person might respond to such a solicitation with violence. State v. Thompson, 767 N.E.2d 251 (Ohio 2002).

116. Local jurisdictions in Florida, Kansas, Louisiana, North Carolina and Texas offered domestic partner health benefits to lesbian and gay public employees at the time that Lawrence was decided. Human Rights Campaign FOUNDATION, THE STATE OF THE WORKPLACE FOR LESBIAN, GAY, BISEXUAL AND TRANSGENDER AMERICANS 2002, at 13 tbl. 3 (2002), available at http://www.hrc.org. Each of those states had a sodomy statute which was invalidated by the Court's decision. ESKRIDGE \& HUNTER, supra note 82, at 76-78. 
recently, seemed the radical question of whether laws limiting marriage to heterosexuals can be justified.

As an institution, however, marriage stands for nothing if not containment, and specifically containment of sexuality. On that point, both the majority and the dissent in Goodridge $v$. Department of Public Health, ${ }^{117}$ for example, agree. The majority opinion essentially substitutes the exclusive commitment of monogamy for the different sexes of the partners as the very definition of marriage, repeatedly drawing on exclusivity as the sine qua non of marriage. ${ }^{118}$ Justice Cordy in dissent accepted that principle, although he put it to different use: "[p]aramount among its many important functions, the institution of marriage has systematically provided for the regulation of heterosexual behavior [and] brought order to the resulting procreation .... The partners in a marriage are expected to engage in exclusive sexual relations, with children the probable result and paternity presumed."119

If Justice Scalia saw with horror an openness to same-sex marriage creeping into the logic of the Kennedy and O'Connor opinions in Lawrence, despite the implicit or explicit disavowals of both authors, ${ }^{120}$ others view the prospect of marital structures for same-sex relationships with alarm for very different reasons. From the perspective of queer legal theory, Lawrence provides both an overdue correction and a new set of problems. To achieve the correction, the Court performed the regulatory function that Gayle Rubin identified more than twenty years ago: the Justices drew the line of social acceptance at a new point in the hierarchy of sexual identities, accepting the most conventional same-sex couples into the realm of "respect," but potentially further isolating those whose lives place them in the regions of disrepute on the wrong side of the line. ${ }^{121}$ Or, to translate into my model, the Court tore down an old wall of containment and built a new one.

\section{798 N.E.2d 941 (Mass. 2003).}

118. Id. at 961 ("[I]t is the exclusive and permanent commitment of the marriage partners to one another ... that is the sine qua non of civil marriage."); id. at 969 ("We construe civil marriage to mean the voluntary union of two persons as spouses, to the exclusion of all others."); id. at 948-49 (defining marriage as "[t] he exclusive commitment of two individuals to each other" and an "intimate, exclusive union"); id. at 965 (noting "marriage's solemn obligation[] of exclusivity"); id. at 969 (maintaining that "the aim of marriage [is] to promote stable, exclusive relationships").

119. Id. at 995 .

120. $123 \mathrm{~S}$. Ct. at 2478 ("whether or not entitled to formal recognition in the law"); see also id. at 2487-88 (O'Connor, J., concurring) (stating that legitimate state interests would include "preserving the traditional institution of marriage").

121. Gayle Rubin, Thinking Sex: Notes for a Radical Theory of the Politics of Sexuality, in Pleasure AND Danger: EXPloring Female SeXuality 267, 282 (Carole S. Vance ed., 1984). 
Professors Kendall Thomas ${ }^{122}$ and Teemu Ruskola ${ }^{123}$ adopt Janet Halley's critique of the Hardwick opinion as equally applicable to Lawrence: "heterosexual identity is the location from which the Justices decide the case without appearing to." ${ }^{24}$ Both argue that the Court's language seeks to subsume gay sex into the norms of domestication associated with marriage, as in the Court's statement that " $[\mathrm{t}] \mathrm{o}$ say that the issue in Bowers was simply the right to engage in certain sexual conduct demeans the claim the individual put forward, just as it would demean a married couple were it to be said marriage is simply about the right to have sexual intercourse." 125 The question this portion of the opinion leaves begging is whether private consensual sexual acts should be protected, independently of relationships. As Ruskola notes, "sex need not be about connection at all; sex can signify intense alienation and separation as much as connection." 126

The re-mapping of sexual respectability evident in the text of Lawrence creates the third major site for contests over containment. Lawrence skirts this issue. The ambiguity of the Court's meaning is reflected in its statement that "intimate conduct with another person ... can be but one element in a personal bond that is more enduring." 127 Queer theorists fear that this statement will be read with particular emphasis, as meaning that intimate conduct with another person can be but one element in a personal bond that is more enduring. Their concern is that long-term commitment will become a prerequisite in future judicial interpretations of the scope of liberty that Lawrence recognizes.

Whether their language was euphemistic or precise, past Justices have framed sexual rights in relational terms. All told, prior to Lawrence, three Justices of the Supreme Court wrote opinions arguing that private adult consensual conduct should be treated as a fundamental right under the Due Process Clause. The earliest, Justice Marshall's, concerned a heterosexual couple fired from their jobs in a public library because of their open cohabitation. ${ }^{128}$ Justice Marshall

122. Kendall Thomas, Our Brown? Reading Lawrence v. Texas (unpublished manuscript).

123. Teemu Ruskola, Gay Rights vs. Queer Theory: What Is Left of Sodomy After Lawrence v. Texas (March 27, 2004) (unpublished manuscript).

124. Janet E. Halley, Reasoning About Sodomy: Act and Identity In and After Bowers v. Hardwick, 79 VA. L. REV. 1721, 1767 (1993). Katherine Franke critiques the case on similar grounds. Katherine M. Franke, The Domesticated Liberty of Lawrence v. Texas, 104 COLUM. L. REV. 1399 (2004).

125. Lawrence, 123 S. Ct. at 2478.

126. Ruskola, supra note 123 , at 17.

127. Lawrence, 123 S. Ct. at 2478.

128. Hollenbaugh v. Carnegie Free Library, 439 U.S. 1052 (1978) (Marshall, J., dissenting from denial of cert.). 
framed the issue as their "rights to pursue an open rather than a clandestine personal relationship" and their "choice of living arrangements for themselves and their child." 129 Justice Brennan, also addressing two heterosexual public employees fired because of their relationship, framed the fundamental right as encompassing "a broad range of private choices involving family life and personal autonomy." 130 Lastly, Justice Blackmun's dissent in Bowers $v$. Hardwick spoke of "the fundamental interest all individuals have in controlling the nature of their intimate associations with others," associations that "form so central a part of an individual's life." 132 However, the Court in Lawrence cited none of these opinions.

Nowhere in the record before the Court was there any indication that the parties in Lawrence had "an enduring personal bond."133 There was thus no basis for the Court to condition the full protection of liberty on the existence of such a relationship. My contention, therefore, is that the sentence will be read with a different emphasis, as meaning that intimate conduct can be but one element in a personal bond ... or not; there is no necessary connection between the two. On this reading, the liberty protection attaches to the intimate conduct in a way that covers all that Lawrence purports to protect: consensual, non-commercial, adult sexual conduct occurring in physically sequestered locations. Moreover, this reading is consistent with the Court's declaration that "it is the right of the individual, married or single" to choose to engage in heterosexual conduct without fear of

129. Id. at 1055-56.

130. Whisenhunt v. Spradlin, 464 U.S. 965, 971 (1983) (Brennan, J., dissenting from denial of cert.).

131. 478 U.S. at 206.

132. Id. at 204.

133. Because Lawrence and Garner entered pleas of nolo contender, the record from the lower courts contained no description of the circumstances of their encounter. Lawrence v. State, 41 S.W.3d 349 (Tex. App. 2001) (en banc). The silence of the record has not impeded the commentary, however. Larry Tribe notes that "[a]pparently, [the relationship between Lawrence and Garner] was quite fleeting, lasting only one night and lacking any semblance of permanence or exclusivity." Laurence H. Tribe, Lawrence v. Texas: The "Fundamental Right" that Dare Not Speak Its Name, 117 HARV. L. ReV. 1893, 1904 (2004). Tribe reads Lawrence - and the "but one element" sentence specifically - as founded on a recognition of the value of relationships and a presumption against allowing governmental intrusion into deeply personal connections, a presumption that he describes the Court as "unflinchingly applying ... despite the seemingly casual character of the encounter involved," because to have done otherwise would have "ceded to the state the power to determine what count as meaningful relationships." Id. at 1905 . In a diametrically opposite reading of that same sentence, Katherine Franke asserts that "the Court took it as a given that Lawrence and Garner were in a relationship, and the fact of that relationship does important normative work in the opinion," i.e., "thorough[ly]... domesticating John Lawrence and Tyron Garner." Franke, supra note 124, at 1408. My own understanding of the facts, based on hearsay, is the same as Tribe's. 
pregnancy. ${ }^{134}$ Any further hierarchic ranking within the category of sexual conduct would raise suspicions of morals-driven selection criteria. Morally neutral considerations - such as the impact of certain couples in a particular workplace - might legitimately lead to regulatory interventions. If that assessment is to be genuinely neutral, however, couplehood will not be a precondition for protection of liberty.

\section{Containment by Analogy}

Despite the significant body of law which has arisen addressing the relationship between sexuality and the state, a conceptual muddiness remains at the core of our understanding of that relationship. Law operates by analogy, and a multi-faceted analogy problem bedevils the law of sexuality.

Sodomy law sought to regulate both acts and identities. In Hardwick, the Court had before it a statute which prohibited acts, by whomever committed, but the Court's opinion created a judicial test which focused on identities. ${ }^{135}$ In Lawrence, the Court created a test which integrated the two, while also recognizing the ways in which the target for direct legal control had shifted over time from acts to identities, leading to a confusion between the two. ${ }^{136}$ Even as the Court made its integrative move, however, the confines of legal doctrine forced it to choose between the two doctrinal handles presented by the petitioners - due process and equal protection - to provide the basis for its decision. ${ }^{137}$ Thus, one central analogic problem is whether principles of liberty or equality most closely fit the question of how law should conceptualize the rights of lesbians and gay men.

Within the equality framework, the second question of analogy becomes how to compare classifications based on sexual orientation to other group-based classifications. Disputes over race generated the Fourteenth Amendment and continue to serve as the central paradigm for all equal protection questions. Whether or to what extent sexual orientation can be compared to race has produced its own body of academic commentary, ${ }^{138}$ now joined by debates over whether $\operatorname{sex}^{139}$ or

134. Eisenstadt v. Baird, 405 U.S. 438, 453 (1972).

135. 478 U.S. at 188 n.1, 192, 196.

136. $123 \mathrm{~S}$. Ct. at $2478-80$.

137. See id. at 2482 .

138. See, e.g., Janet E. Halley, Gay Rights and Identity Imitation: Issues in the Ethics of Representation, in THE POLITICS OF LAW: A PROGRESSIVE CRITIQUE 115 (David Kairys ed., 3d ed. 1998); Devon W. Carbado, Black Rights, Gay Rights, Civil Rights, 47 UCLA L. REV. 1467 (2000); Darren Lenard Hutchinson, "Gay Rights" for "Gay Whites"?: Race, Sexual Identity, and Equal Protection Discourse, 85 CORNELL L. REV. 1358 (2000); Sharon Elizabeth Rush, Equal Protection Analogies - Identity and "Passing": Race and Sexual 
religion ${ }^{140}$ might furnish a closer comparison to sexual orientation. That debate has not reached the Supreme Court, however. The Court has assiduously avoided the question of classification analogy, opting instead for the default mechanism of rational basis review, supplemented by a higher standard for rationality, for sexual orientation classifications, as was evident in Romer v. Evans, now clarified by Justice O'Connor's concurring opinion in Lawrence. ${ }^{141}$

Nor do liberty and equality exhaust the field of doctrinal possibilities. To a much greater extent than in prior civil rights movements, expression and voice form a key component of gay rights struggles. Coming out creates the stigmatized identity. Thus the doctrinal basis for the protection of coming-out speech - the First Amendment - plays a fundamental role in questions of either autonomy or equality for gay people. ${ }^{142}$

Lawrence offers no guidance on any of these aspects of analogy appropriateness and appropriation. Perhaps over time, one of the foregoing themes or doctrines will come to dominate in the law of sexual orientation. In the meantime, analogic confusion is likely to continue.

There is a bright side to the analogy problem, however: uncertainty can operate as positive openness and not merely as avoidance. Declining to specify an analogy for sexual orientation carries the political advantage of judicial minimalism, postponing closure on a divisive social issue until the political branches are more uniformly

Orientation, 13 HARV. BLACKLETTER L.J. 65 (1997); Margaret M. Russell, Lesbian, Gay and Bisexual Rights and "The Civil Rights Agenda," 1 AFR.-AM. L. \& POL'Y REP. 33 (1994).

139. A number of articles examine the analogy between sex and sexual orientation discrimination, but most of the arguments are captured by a recent exchange: Edward Stein, Evaluating the Sex Discrimination Argument for Lesbian and Gay Rights, 49 UCLA L. REV. 471 (2001) and Andrew Koppelman, Defending the Sex Discrimination Argument for Lesbian and Gay Rights: A Reply to Edward Stein, 49 UCLA L. REV.519 (2001).

In the Texas state courts, Lawrence and Garner relied on the state's Equal Rights Amendment to argue that because the sodomy statute criminalized certain conduct only if the two persons were of the same sex, proof of defendants' sex was a necessary element of the crime, an example of per se discrimination. Lawrence v. State, 41 S.W.3d 349 (Tex. App. 2001) (en banc). In the Supreme Court, counsel for the two men elected to forego the sex discrimination argument entirely, although it could have been used as an alternative basis for arguing a violation of the federal Equal Protection Clause. See Brief for Petitioners, Lawrence v. Texas, 123 S. Ct. 2472 (2003) (No. 02-102). Bypassing sex discrimination allowed the attorneys to avoid a line of argument that would have been far more difficult to distinguish from challenges to marriage statutes, since all exclusionary marriage laws utilize the same distinction based on sex of partners that the Texas sodomy law embodied.

140. The most forceful argument that religion furnishes the closest comparison to sexual orientation is DAVID A.J. RICHARDS, IDENTITY AND THE CASE FOR GAY RIGHTS: RACE, GENDER, RELIGION AS ANALOGIES (1999).

141, 123 S. Ct. at 2485 (O'Connor, J., concurring).

142. ESKRIDGE \& HUNTER, supra note 82, at 321-70; Nan D. Hunter, Expressive Identity: Recuperating Dissent for Equality, 35 HARV. C.R.-C.L. L. REV. 1 (2000). 
aligned on the illegitimacy of antigay bias. Moreover, although the logic of legal argument will press both advocates and courts to identify and elaborate analogy more clearly, not pinning down the closest comparison may prove the most liberating move in the long run, as well as a politically pragmatic move in the short run.

There is no intrinsic, ahistorical best doctrine for sexual orientation. Of course, "best" could be defined as most powerful in ending oppression or as least disruptive of the social order or in any number of other ways. But even if one accepts that "best" should mean most efficacious in equalizing the power relationship between the majority and the socially subordinate group, there is no always right answer. Many women's rights advocates chafed at the language in Roe $v$. Wade which grounded the right to choose abortion as much with the physician as with the pregnant woman, and it became a common argument that the decision would have been far more powerful had it been based on sex equality, rather than due process privacy, grounds. ${ }^{143}$ Ironically, however, in Lawrence $v$. Texas, most observers have understood the equal protection claim to be weaker than the due process claim. ${ }^{144}$ Had winning on due process not necessarily entailed the reversal of Hardwick, however, the opposite perception of Lawrence might well have dominated.

With the onus of Hardwick removed, one can at least imagine examinations of the regulation of homosexuality that could step beyond the group-based focus and substitute a model of analysis built on the understanding that classifications emerge from structures and systems of subordination. A shortcoming of analogy disputes is that they tend to produce simplistic models of hierarchy. In the field of sex discrimination, for example, courts have framed the question of whether a practice discriminates based on sex as synonymous with the question of whether it discriminates against women, or perhaps against men. ${ }^{145}$ Framing the question in that way, rather than as a broader interrogation of gender, precludes the strongest modes of anti-subordination argument.

Using a focus on structures of subordination would direct attention to a broad range of ideologies of superiority, prevailing cultural and social norms, and material consequences of oppressive practices. An

143. See, e.g., Ruth Bader Ginsburg, Some Thoughts on Autonomy and Equality in Relation to Roe v. Wade, 63 N.C. L. REV. 375 (1985); Sylvia A. Law, Rethinking Sex and the Constitution, 132 U. PA. L. ReV. 955 (1984); Donald H. Regan, Rewriting Roe v. Wade, 77 MICH. L. REV. 1569, 1621-45 (1979).

144. See Tribe, supra note 133 , at 1907-16.

145. The lower court in Lawrence used this argument as part of the basis for its ruling that the Texas Equal Rights Amendment did not apply. Lawrence v. State, 41 S.W.3d 349, 359 (finding that the sodomy law produced no "disparate impact between men and women"). 
expansive notion of full citizenship turns on freedom from all such systems of social control.

\section{CONCLUSION}

Lawrence $v$. Texas marked a dramatic milestone in efforts to limit state power to control homosexuality, but the product is likely to be a different regulatory regime rather than a libertarian utopia (or dystopia, depending on one's perspective). Law long ago ceased to be effective in prohibiting consensual conduct, and has instead functioned as a critically important venue for multiplying the discourses of sexuality. Under the regime of Lawrence, courts will continue to operate as mediating institutions, adjudicating the contest between equality demands and efforts at containment. 